\title{
PARADIGM AND REALITY OF LAW ENFORCEMENT \\ IN INDONESIA
}

Rosdalina Bukido

\begin{abstract}
The research on "PARADIGM AND REALITY OF LAW ENFORCEMENT IN INDONESIA" is a library research, which aims to investigate about the factors influencing failed law enforcement in Indonesia.

The good law enforcement is one of the criterions success nation to increase the dignity specially in law. Law should protect all societies living anywhere. So, it can create stability and safety life of our societies. There are many functions of law. Law can make the good thing for all sectors, for example economic, politic, trade, etc.

Paradigm and reality of law enforcement in Indonesia is not carried out well yet. It is caused by two factors. They are officers of law enforcement (judge, police, advocate, and public prosecutor). If they have the good morality and integrity, law enforcement can run well. The second is Indonesian legislative assembly as the makers of law. Although the makers of law are not socialization with societies directly, but the result of them can reach and cover all problems in Indonesian

societies.
\end{abstract}

Key words: Paradigm, Reality, Law Enforcemen

\section{A. Pendahuluan}

Salah satu agenda reformasi hukum yang penting dan mendesak untuk di laksanakan adalah reformasi dalam penegakan hukum. Penegakan hukum (law enforcement) yang dapat dilakukan dengan baik dan efektif merupakan salah satu tolok ukur keberhasilan suatu Negara dalam upaya mengangkat harkat dan martabat bangsanya di bidang hukum terutama dalam memberikan perlindungan hukum terhadap warganya.

Hal ini berarti pula adanya jaminan kepastian hukum bagi rakyat, sehingga rakyat merasa aman dan terlindungi hak- haknya dalam menjalani kehidupannya. Sebaliknya penegakan hukum 
yang tidak berjalan sebagaimana mestinya merupakan indikator bahwa Negara yang bersangkutan belum sepenuhnya mampu memberikan perlindungan hukum kepada warganya.

Perlindungan hukum terhadap masyarakat merupakan kewajiban bagi semua pihak. Namun, tugas tersebut merupakan kewajiban mutlak bagi Polisi sebagai pengayom masyarakat yang diharapkan mampu menciptakan keamanan dan kenyamanan di lingkungan sekitarnya. Akan tetapi, secara realita keamanan dan kenyamanan sebagai implikasi dari tegaknya law en- forcement di masyarakat belum tercipta secara maksimal. Olehnya itu, muncul sebuah permasalahan pokok bahwa faktor-faktor apakah yang mempengaruhi sehingga penegakan hukum di Indonesia belum tercapai sebagaimana yang diinginkan?

\section{B. Pembahasan}

\section{Paradigma dan realita penegakan hukum di Indonesia}

Dalam berbagai kajian sistematis penegakan hukum dan keadilan, secara teoritis menyatakan bahwa efektifitas penegakan hukum baru akan terpenuhi apabila 5 pilar hukum dapat berjalan dengan baik. Lima pilar hukum itu adalah instrumen hukumnya, aparat penegak hukumnya, peralatannya, masyarakatnya dan birokrasinya. ${ }^{1}$

Lemahnya law enforcement di Indonesia menyebabkan aparat penegak hukum menjadi sorotan, kepercayaan masyarakat terhadap aparat sudah mencapai titik memprihatinkan, salah satu indikasinya adalah banyaknya tindakan rakyat kecil yang melakukan perbuatan main hakim sendiri (eigenrichting).

Dengan adanya integrated criminal justice sistem yang melahirkan lembaga catur wangsa Polisi, Jaksa, Penasehat hukum dan Hakim, keempat aparat tersebut sudah menjadi ejekan masyarakat, istilah "pajak memaksa" buat Jaksa, "Advokat hitam" buat penasehat hukum dan hubungi aku kalau ingin menang" buat Hakim, begitu pula istilah mafia peradilan kalimat tersebut sudah mernbahana. ${ }^{2}$

\footnotetext{
${ }^{1}$ Bambang Sutiyoso, Aspek-aspek Perkembangan Kekuasaan Kehakiman Di Indonesia, (Yogyakarta: UII Press, 2005), hal. 78.

${ }^{2}$ Sahlan Said, Seminar Reaktualisasi Peran Fakultas Hukum Sebagai Lembaga Pendidikan dan Pengajaran bagi Insan Hukum dan Program Riset Kolaboratif Tim Task Force IF-LPD, Yogyakarta, 2004
} 
Diantara keempat aparat tersebut sebenarnya kedudukan hakimlah yang paling startegis, dia adalah benteng terakhir bagi yustiabellen (pencari keadilan), hakim bukan hanya corongnya undang-undang "speaker of law" akan tetapi ia harus menjadi corongnya keadilan "speaker of justice".

Betapa luhurnya jabatan seorang hakim sampai-sampai ia diberi hak untuk mengatasanamakan Tuhan dalam mengambil keputusan. Sebagai benteng terakhir seharusnya ia memiliki atau menguasai sesuatu yang lebih dari aparat penegak hukum yang lain baik dalam bidang hukum maupun moral.

Hakim sebagai tempat pelarian terakhir merupakan tumpuan dah harapan masyarakat, hakim diharapkan menjadi "ultimum remedium" maka ia harus sanggup menjadi senjata pamungkas bagi semua ketidakbenaran, silahkan aparat yang lain rusak asalkan hakim tidak, insya Allah keadilan akan dapat ditegakkan.

Masalah penegakan hukum pada dasarnya merupakan kesenjangan antara hukum secara normative (das sollen) dan hukum secara sosiologis (das sein) atau kesenjangan antara perilaku hukum masyarakat yang seharusnya dengan perilaku hukum masyarakat yang senyatanya.

Roscoe pound menyebutnya sebagai perbedaan antara "law in the book dan law in action". Perbedaan ini mencakup persoalan-persoalan antara lain :

1. Apakah hukum di dalam bentuk peraturan yang telah diundangkan itu mengungkapkan pola tingkah laku sosial yang ada waktu itu.

2. Apakah yang dikatakan pengadilan itu sama dengan apa yang dilakukannya.

3. Apakah tujuan yang secara tegas dikehendaki oleh suatu peraturan itu dalam kenyataan.

Secara konsepsional, inti dan arti penegakan hukum terletak pada kegiatan menyerasikan hubungan nilai-nilai yang terjabarkan di dalam kaidah-kaidah yang mantap dan mengejewantah dan sikap tindak sebagai rangkaian penjabaran nilai tahap akhir, untuk menciptakan memelihara dan mempertahankan kedamaian pergaulan hidup. ${ }^{3}$

\footnotetext{
${ }^{3}$ Soerjono Soekanto, Faktor-faktor yang Mempengaruhi Penegakan Hukum, (Jakarta: Rajawali, 1983$)$, hal.
} 
Hukum sebagai suatu kaidah di dalamnya merupakan seperangkat norma- norma yang memuat anjuran, larangan dan sanksi yang salah satu fungsi pokoknya sebagai sarana kontrol sosial, dengan tujuan menjaga ketertiban, keseimbangan sosial dan kepentingan masyarakat. Sebagai seperangkat norma yang berfungsi dan bertujuan demikian itu, maka hukum pertamatama akan hadir sebagai sesuatu yang bersifat law in the books, memuat ancangan hipotesis tentang batas-batas perilaku manusia yang boleh dan tidak boleh dilakukan serta memberi ancaman sanksi apabila ada di antara anggota masyarakat yang melakukan pelanggaran.

Pada taraf law in the books ini, hukum belum banyak dirasakan manfaatnya oleh masyarakat karena ia belum berjalan, bergerak dan berfungsi seperti apa yang dijanjikannya. Ia baru akan dirasakan manfaatnya atau bahkan dirasakan dampaknya setelah ia ditegakkan di tengah-tengah masyarakat (law in actions). Oleh karena itu tidak mengherankan jika ada pernyataan, bahwa hukum tidak bisa disebut sebagai hukum, manakala ia tidak pernah dilaksanakan. Oleh karena itu norma- norma hukum yang berisi anjuran, larangan dan sanksi perlu adanya konkritisasi dan operasionalisasi dengan ditegakkannya hukum secara sungguh-sungguh terutama oleh aparat penegak hukumnya.

Pola penegakan hukum dipengaruhi oleh tingkat perkembangan masyarakat, tempat hukum tersebut berlaku dan diberlakukan. Dalam masyarakat sederhana, pola penegakan hukumnya dilaksanakan melalui prosedur dan mekanisme yang sederhana pula. Namun dalam masyarakat modern yang bersifat rasional dan memiliki tingkat spesialisasi dan diferensiasi yang begitu tinggi, pengorganisasian penegakan hukumnya menjadi begitu kompleks dan sangat birokrasi.

Semakin modem suatu masyarakat, maka akan semakin kompleks dan semakin birokratis proses penegakan hukumnya. Sebagai akibatnya, yang memegang peranan penting dalam proses penegakan hukum bukan hanya manusia yang menjadi aparat penegak hukum, namun juga organisasi yang mengatur dan mengelola operasionalisasi proses penegakan hukum.

Kondisi penegakan hukum dalam masyarakat bukan hanya ditentukan oleh faktor tunggal, melainkan dipengaruhi oleh berbagai faktor, yang memberikan kontribusi secara bersama-sama terhadap kondisi tersebut. Namun faktor mana yang paling dominan mempunyai pengaruh tergantung pada kepada konteks sosial dan tantangan-tantangan yang dihadapi masyarakat bersangkutan. 
Secara umum faktor-faktor yang mempengaruhi penegakan hukum dapat dibedakan dalam dua hal, yaitu faktor- faktor yang terdapat dalam sistem dan faktorfaktor di luar sistem hukum. Adapun faktor-faktor dalam sistem hukum meliputi faktor hukumnya (undang-undang), faktor penegak hukum, dan faktor sarana dan prasarana. Sedangkan faktor di luar sistem hukum yang memberikan pengaruh adalah faktor kesadaran hukum masyarakat, perkembangan masyarakat, kebudayaan dan faktor politik atau penguasa Negara. ${ }^{4}$

Faktor hukum dan perundang-undangan berkaitan dengan:

a) Konsistensi asas-asas atau prinsip- prinsipnya. Apakah antara satu asasdengan asas yang lain tidak saling menegasikan atau bertentangan,

b) Proses perumusannya; apakah memperhatikan kecenderungan hukum- hukum kebiasaan yang berlaku di masyarakat, dan apakah penyusunannya cukup demokratis dengan memperhatikan aspirasi masyarakat yang berkembang, dan

c) Tingkat kemampuan hukum itu sendiri dalam operasionalisasinya, sebab tidak jarang ada sejumlah undang-undang yang tidak operasional, baik karena konsepnya tidak jelas, juga karena keharusannya untuk ditindaklanjuti dengan aturan pelaksanaan, yang acapakali terlalu lama sehingga kalaupun aturan pelaksanaan itu pada akhirnya sudah tidak relevan lagi dengan perkembangan yang ada dan seterusnya.

Faktor yang berkaitan dengan sumber daya aparatur penegak hukumnya. Aparatur penegak hukum ini merupakan faktor kunci, karena di pundak merekalah terutama beban penegakan hukum diletakkan dalam praktek. Oleh karena itu keberhasilan dan kegagalan proses penegakan hukum sangat dipengaruhi oleh kualitas penegak hukum, apakah penegak hukum itu profesional atau tidak. Arti penting penegak hukum profesional semakin terasa jika dikaitkan dengan realitas sosial yang penuh dengan ketimpangan dalam struktur sosial, ekonomi, politik, pendidikan, maupun kekuasaan walaupun profesionalisme ini mempunyai arti penting dalam proses penegakan hukum, namun saying semangat profesionalisme ini semakin mengalami kemerosotan di kalangan aparat penegakan hukum kita. Kurangnya profesionalisme ini terlihat dari lemahnya wawasan permikiran dan minimnya keterampilan untuk bekerja, rendahnya motivasi kerja dan rusaknya moralitas personal aparat penegak hukum. Kurangnya

\footnotetext{
${ }^{4}$ Bambang Sutiyoso, hal. 80
} 
profesionalisme aparat ini disebabkan tingkat pendidikan yang rendah, dan sangat sedikitnya program sumber daya di kalangan organisasi penegakan hukum.

Faktor sarana dan prasarana; apakah aparat penegak hukum sudah dilengkapi dengan sarana dan prasarana fisik yang memadai, khususnya alat-alat teknologi modern dalam rangka sosialisasi hukum dan mengimbangi kecenderungan-kecenderungan penyimpangan sosial masyarakat, termasuk ketersediaan sarana dan prasarana tempat menjalani pidana dan seterusnya.

Gangguan dalam kelancaran proses penyelesaian penegakan hukum oleh lembagalembaga hukum, disebabkan oleh tiadanya keseimbangan antara falilitas pengadministrasian dengan jumlah orang yang harus dilayani, dapat diperkirakan akan menimbulkan peluang bagi terjadinya cacat dalam administrasi tersebut. Dalam pengertian ini termasuk baik kemunduran mutu pelaksanaan maupun praktik-praktik yang sudah mengarah kepada perbuatan terlarang. ${ }^{5}$

Faktor yang berkaitan dengan persepsi masyarakat tentang hukum, tentang ketertiban dan fungsi penegak hukum. Dalam kenyataannya, terutama masyarakat yang masih kuat memgang teguh hukum rakyat (folks law) pemahaman tentang apa itu hukum, apa itu ketertiban dan apa itu penegak hukum bisa berbeda dengan yang dimaksudkan oleh hukum modern, sehingga di sini diperlukan penjabaran yang jelas menyangkut masalah ini.

Faktor terakhir adalah faktor politik atau penguasa Negara, khususnya deskripsi tentang campur tangan pemerintah dan kelompok-kelompok kepentingan di dalam usaha-usaha penegakan hukum. Faktor ini patut diperhatikan karena pada kenyataannya penegakan hukum itu tidak sekali-kali hanya diperuntukkan kepada masyarakat kecil pedesaan, tetapi semua lapisan masyarakat, sehingga kemungkinan campur tangan dari kekuatan-kekuatan kepentingan dalam masyarakat sangat besar. Dalam proses peradilan, terkadang kita jumpai adanya intervensi pihak eksekutif atau lembaga ekstra yudisial lainnya dalam proses perkara yang sedang berlangsung. Campur tangan lembaga-Iembaga tersebut membatasi kebebasan hakim dalam memeriksa dan mengadili perkara, sehingga proses peradilan yang jujur dan tidak memihak tidak berjalan dengan baik. Intervensi lembaga eksekutif dan lembaga-lembaga ekstra yudisial tersebut terjadi dalam peradilan kasus-kasus kejahatan politik, misalnya dalam pemeriksaan kasus-kasus

\footnotetext{
${ }^{5}$ Satjipto Rahardjo, Persoalan Hukum Dalam Masyarakat, (Bandung: Angkasa, 1988), hal.11
} 
subversi dan penyebaran kebencian kepada pemerintah. Dan dapat pula terjadi bila pihak yang diadili adalah pejabat-pejabat penting.

Selanjutnya faktor-faktor di luar sistem hukum yang berpengaruh terhadap proses penegakan hukum adalah kesadaran hukum masyarakat dan perubahan sosial. Kesadaran hukum masyarakat kita masih rendah, baik di kalangan masyarakat terdidik maupun di seputar masyarakat kurang berpendidikan, bahkan juga di kalangan penegak hukum sendiri.

Indikator rendahnya kesadaran hukum masyarakat dapat dilihat dari banyaknya tindakan main hakim sendiri yang terjadi dalam masyarakat, baik yang dilakukan masyarakat pada umumnya, maupun yang dilakukan aparat penegak hukum. Para pelaku kejahatan yang tertangkap basah saat melakukan kejahatan, terutama pelaku kasus kejahatan kesusilaan, pencurian dan persantetan dihakimi sendiri oleh masyarakat.

Oleh karena itu, jika kita mencermati fenomena perilaku kekerasan dan anarki yang kini semakin merebak, saya berpendapat bahwa karena akar masalah merebaknya kekerasan adalah buruknya tingkat kepercayaan adalah buruknya tingkat kepercayaan warga masyarakat terhadap pemerintah dan penegak hukum, maka langkah yang paling awal yang seyogyanya dilakukan adalah mengembalikan kepercayaan warga masyarakat terhadap hukum dan penegakan hukum. Dalam hal ini, Mahkamah Agung Republik Indonesia-Iah "ujung tombak" untuk memulihkan kepercayaan warga masyarakat terhadap law enforcement.

Untuk itu tentunya dibutuhkan para hakim agung yang berwawasan luas, memiliki kedalaman ilmu hukum, mempunyai kedekatan dengan rasa keadilan rakyat banyak, dan tidak berkiblat kepada kepentingan politik partai atau golongan tertentu. Hanya dengan inilah, insya Allah Indonesia dapat memulai perbaikan di dunia peradilan khususnya, dan law enforcement pada umumnya.

Sudah saatnya kita di Indonesia merevisi apa yang kita persepsikan sebagai "hukum". Orang-orang Amerika yang sekuler saja, kini telah berteriak: "kembalikan hukum ke akar moralitas, kultural, dan religiusnya". Orang-orang Amerika yang berpikiran : "the critical legal studies movemen", mengecam formalisme dan prosedural yang ditonjolkan selama ini dalam law enforcement, sembari meninggalkan the sense of justice of people (rasa keadilan rakyat) yang sebenarnya. 
Kita harus berjuang agar hukum dapat dikembalikan pada akar moralitasnya, akar kulturnya dan akar religiusnya. Sebab, dengan cara itu masyarakat akan merasakan hukum itu cocok dengan nilai-nilai instrinsik yang mereka anut. Sepanjang aturan hukum yang ada tidak sesuai dengan nilai-nilai intrinsik warga masyarakat, maka ketaatan hukum yang muncul hanyalah sekedar ketaatan yang bersifat compliance (taat hanya karena takut sanksi), dan bukan ketaatan yang bersifat internalization (taat karena benar-benar menganggap aturan hukum itu cocok dengan nilai intrinsik yang dianutnya)

\section{Hukum sebagai produk politik}

Di kalangan ahli hukum minimal ada dua pendapat mengenai hubungankausalitas antara politik dan hukum. Kaum idealis yang lebih berdiri pada sudut das sollen mengatakan bahwa hukum harusmmengendalikan dan merekayasa perkembangan masyarakat, termasuk kehidupan politiknya. Roscou Pound telah lama berbicara bahwa "law as a tool of social engineering". Sebagai keinginan tentu saja wajar jika ada upaya untuk meletakkan hukum sebagai penentu arah perjalanan masyarakat karena dengan itu fungsi hukum untuk menjamin ketertiban dan melindungi kepentingan masyarakatnya akan menjadi relevan. Tetapi kaum realis seperti Savigny mengatakan bahwa "hukum selalu berkembang sesuai dengan perkembangan masyarakatnya". Ini berarti bahwa hukum, mau tidak mau, menjadi independent variable atas keadaan di luarnya, terutama keadaan politiknya.

Memang di dalam kenyataannya hukum itu lahir sebagai refleksi dari konfigurasi politik yang melatarbelakanginya. Dengan kata lain kalimat-kalimat yang ada di dalam aturanhukum itu tidak lain merupakan kristal isasi dari kehendak-kehendak poilitik yang saling bersaingan. ${ }^{6}$

Satjipto Rahardjo (1985:71) mengemukakan bahwa kalau kita melihat hubungan antara subsistem hukum, tampak bahwa politik memiliki konsentrasi energi yang lebih besar sehingga hukum selalu berada pada posisi yang lemah. Pengaruh politik terhadap hukum dapat berlaku terhadap penegakan hukumnya dan karakteristik produk- produk serta proses pembuatannya.

\footnotetext{
${ }^{6}$ Moh, Mahfud MD, Pergulatan Politik dan Hukum Di Indonesia, (Yogyakarta: Gama Media, 1999), hal.
} 
Bahwa keadaan politik tertentu dapat mempengaruhi produk hukum, untuk kasus Indonesia kita dapat melihat kasus lahirnya Undang-undnag No. 1 Tahun 1974 tentang Perkawinan. Undang-undang tersebut lahir pada era orde baru, tetapi hubungan politik antara Negara dengan Agama yang melatarbelakanginya berada dalam suasana yang berbeda. Undangundang Perkawinan lahir dalam keadaan politik konflik dan saling curiga. RUU tentang perkawinan yang diajukan pada periode konflik politik ternyata menyebut protes dan demintrasi karena materinya memuat banyak hal yang bertentangan dengan ajaran Islam. Pada saat itu pemerintah yang tidak mesra dengan Islam mengajukan RUU yang dipandang dari sudut aqidah Islam harus ditolak, sementara orang Islam sendiri yang sedang "agak" oposan dengan pemerintah mencurigai RUU tersebut sebaga upaya mengecilkan Islam. Maka, jelas bahwa politik saling mencurigai dan konflik itu melahirkan rancangan produk hukum yang juga menggambar kesalingcurigaan.

Demikian pula Rancangan Undang- Undang Anti Pornografi dan Pornoaksi (RUUAPP) yang sedang digodok sekarang ini menimbulkan polemik berkepanjangan. Organisasi Masyarakat (Ormas) Islam tetap memperjuangkan agar RUUAPP tersebut disahkan menjadi Undang-undang. Perilaku sebagian warga masyarakat yang notabene mayoritas Islam meresahkan masyarakat dan menyimpang dari norma- norma keagamaan. Jika RUUAPP tersebut terkontaminasi dengan unsur politik yang identik dengan kekuasaan, saya yakin pelaksanaannya menghadapi rintangan. Pro kontra berbagai elemen masyarakat dalam menyikapi RUUAPP tersebut mengindikasikan bahwa Indonesia melahirkan generasi yang cerdas tetapi belum tentu bijaksana. Sebab,jika kita sadar bahwa implikasi dari RUUAPP yang nantinya disahkan menjadi undang- undang disepakati bersama pembentukannya maka akan melahirkan ketertiban, keamanan, kenyamanan dalam masyarakat sehingga mempengaruhi kestabilan masyarakat Indonesia pada berbagai aspek.

Olehnya itu, perilaku aparat penegak hukum mencakup Polisi, Advokat, Jaksa dan Hakim kiranya dapat mengembalikan kepercayaan warga masyarakat terhadap hukum. Mari kita kembalikan hukum kepada moralitas dan religiusnya. Seorang filosof (Taverne) pernah menyatakan, "Berikan saya seorang jaksa jujur dan cerdas, berikanlah saya seorang hakim yang jujur dan cerdas, maka dengan undang-undang yang paling buruk pun, saya akan menghasilkan putusan yang adil". 
Mengutip pendapat PC Siswanto (Opini Kompas 23 Mei 2006) bahwa "Selama proses pendidikan tetap bermodel pengajaran, transfer ilmu pendidikan hanya melahirkan orang- orang pintar belum tentu benar, ahli tetapi belum tentu rendah hati, cerdas tetapi belum tentu bijaksana".

Jika para penegak hukum dapat menerapkan dan memegang teguh prinsip tersebut tentunya law enforcement yang kita harapkan bersama dapat terlaksana dengan baik. Polisi, Jaksa, Advokat dan Hakim merupakan out put pendidikan formal yang telah menggeluti pendidikan hukum diharapkan mampu mengayomi masyarakat dengan mengedepankan pola intelektual dan integritas tinggi.

\section{Kesimpulan}

Paradigma law enforcement tidak berjalan seperti apa yang diharapkan. Hal ini dipengaruhi oleh berbagai faktor. Yang pertama adalah aparat penegak hukum, yaitu Polisi, Hakim, Jaksa dan advokat. Adalah kewajiban bagi mereka untuk mengembalikan kepercayaan masyarakat terhadap hukum. Hal ini dapat berjalan dengan baik jika penegak hukum mengedepankan intelektualitas dan integritas dalam menyikapi persoalan hukum di masyarakat. Yang kedua adalah pembentuk undang-undang. Walaupun pembentuk undang-undang tidak bersentuhan langsung dengan masyarakat sebelum merumuskan rancangan undang- undang, seyogyanya mereka mengetahui lebih awal kondisi yang terjadi di masyarakat, sehingga produk undang-undang tersebut mengenai sasaran. 


\section{DAFTAR PUSTAKA}

Ali, Achmad, Keterpurukan Hukum Di Indonesia (Penyebab dan Solusinya), Jakarta: Ghalia Indonesia,2002

--------, Menguak Tabir Hukum (Suatu Kajian Filosofis dan Sosiologis), Jakarta: Chandra Pratama, 1996

Lev, Daniel S, Hukum dan Politik Di Indonesia Kesinambungan dan Perubahan, Jakarta: LP3ES, 1990

Mahfud, Moh, Pergulatan Politik dan Hukum di Indonesia, Yogyakarta: Gama Media, 1999

PC Siswanto, "Opini," Kompas 23 Mei 2006

Sutiyoso, Bambang, dan Puspitasari, Sri Hastuti, Aspek-aspek Perkembangan Kekuasaan Kehakiman Di Indonesia, Yogyakarta: UII Press, 2005

Zakiyah, Wasingatu, Menyingkap Tabir Mafia Peradilan, Jakarta: ICW, 2002 